\title{
CHANGES IN BOTANICAL COMPOSITION OF ALFALFA MIXTURES DEPENDING ON THE SPECIES AND N FERTILIZATION
}

\section{Z. Nešić ${ }^{1 *}$, Z. Tomić ${ }^{1}$, S. Vučković ${ }^{2}$, V. Krnjaja ${ }^{1}$, S. Josipović ${ }^{1}$, D. Ružić-Muslić ${ }^{1}$}

\author{
${ }^{1}$ Department for forage crops and ecology, Institute for Animal Husbandry, Belgrade, Serbia \\ ${ }^{2}$ Faculty of Agriculture, Zemun-Belgrade, Serbia \\ *Corresponding author: znesic77@yahoo.com \\ ** Original scientific paper- Research financed by the Ministry of Science of Republic of \\ Serbia, Project TR 6872
}

\begin{abstract}
Alfalfa is the most important forage plant in our country. It is mainly grown as pure crop for livestock nutrition, although it gives very good results when grown in mixture with other plant species. By growing in mixtures many advantages are achieved, the most important are: possibility for alfalfa to be used in grazing and reduced need for fertilization of grassland. In two year trial (2003-2004), changes in botanical composition of alfalfa mixtures depending on the present species in the mixture, i.e. their competitive abilities and fertilization with $\mathrm{N}$, were monitored. Investigations showed that by ageing of crops the share of grasses increases and share of legumes and weeds decreases. Fertilization showed positive effect on strengthening of competitive abilities of grass in relation to leguminous species and increased share of weeds in forage mixtures.
\end{abstract}

Key words: grass-leguminous mixtures, botanical composition, $\mathrm{N}$ fertilization

\section{Introduction}

Alfalfa is the most important forage plant in the world and in our country. It is used for nutrition of all domestic animals mainly as pure crop, but also in combination with other leguminous plant or grass. Growing of alfalfa offers many advantages: possibility of utilization of this plant through grazing (Ocokoljić et al., 1984), equal influx of livestock feed from pastures during entire vegetation season (Hoveland et al., 1995) reduced need for 
application of $\mathrm{N}$ fertilizer due to nitrogen fixating abilities of alfalfa (Tekeli and Ates, 2005), providing of necessary amounts of sugar for successful ensiling (Đorđević and Dinić, 2003) and increase of digestibility (White and Wight, 1984).

In composing of grass-leguminous mixtures the selection of plant species is very important. By correct choice of species for artificial grasslands, for selected region and use of certain agro techniques, the yield, the quality and distribution of crops are influenced. Compatibility of grasses and legumes depends on morphological and physiological characteristics of species, characteristics of given association, its interaction with applied agrotechnical measures, but also climate, edaphic and biological conditions under which the association is developing (Frame and Laidlaw, 1998).

Application of nitrogen mineral fertilizers reduces the nitrogen fixating abilities of leguminous species, which leads to weakening of their competitive abilities and strengthening of the competitive abilities of grass species. So, Berdahl et al. (2001) concluded that addition of $\mathrm{N}$ mineral fertilizers in the amount of $50 \mathrm{~kg} \mathrm{ha}^{-1}$ did not increase the yields of mixture, but favoured the grass component and its share in total yield of mixture. Objective of this research was to determine the influence of applied $\mathrm{N}$ on botanical composition of mixture in order to determine the optimal dose of nitrogen in given agro-ecological conditions for fertilization of mixtures.

\section{Material and methods}

Aiming to solve the described task a two factorial trial was set according to method of random block system in four repetitions in duration of two years (2003-2004). Surface of main parcel was $10 \mathrm{~m}^{2}$. Investigations included following factors: mixtures with different shares of alfalfa: mixture I (alfalfa $50+$ cock's foot 50\%), mixture II (alfalfa 33,3 + cock's foot 33,3+ tall fescue 33,3\%), mixture III (alfalfa $25+$ cock's foot $25+$ tall fescue $25+$ sain foin 25\%) and amount of pure $\mathrm{N}$ from mineral fertilizer $\operatorname{KAN}(70,140$, $210 \mathrm{~kg} \mathrm{ha}^{-1}$ ). Botanical composition of mixtures was determined by taking samples of green mass prior to each cut from $1 \mathrm{~m}^{2}$. Individual plant species were separated from the sample, than dried and based on their weight share the relative presence in mixture determined.

\section{Agro ecological conditions}

Soil where trial was set is poor carbonate chernozem, it is of good granular structure, and according to granulometric composition it belongs to 
floury clay.

Chemical traits (tab.1) show that soil is of neutral to slight alkaline reaction with very low content of $\mathrm{CaCO}_{3}$. Contents of humus and total nitrogen are satisfactory and within the normal limits, whereas the content of phosphorus very high. K shows lower presence than average values.

Table 1. Chemical characteristics of soil on which trial was set

\begin{tabular}{|c|c|c|c|c|c|c|c|c|c|}
\hline \multirow{2}{*}{$\begin{array}{l}\text { Depth } \\
\text { (cm) }\end{array}$} & \multicolumn{2}{|c|}{$\begin{array}{c}\text { Acidity } \\
\text { (pH) }\end{array}$} & \multirow{2}{*}{$\begin{array}{c}\text { Org. } \\
\text { mat.(\%) }\end{array}$} & \multirow{2}{*}{$\begin{array}{c}\text { Humus } \\
(\%)\end{array}$} & \multirow{2}{*}{$\begin{array}{c}\mathrm{CaCO}_{3} \\
(\%)\end{array}$} & \multicolumn{2}{|c|}{$\mathrm{N} \mathrm{mg/1000g}$} & \multirow{2}{*}{$\begin{array}{c}\mathrm{P}_{2} \mathrm{O}_{5} \\
\mathrm{mg} / 100 \mathrm{~g}\end{array}$} & \multirow{2}{*}{$\begin{array}{c}\mathrm{K}_{2} \mathrm{O} \\
\mathrm{mg} / \mathbf{1 0 0 g}\end{array}$} \\
\hline & $\mathrm{H}_{2} \mathrm{O}$ & $\mathrm{KCl}$ & & & & Total & $\mathrm{NO}_{3}{ }^{-}$ & & \\
\hline $0-20$ & 7,29 & 7,08 & 7,09 & 4,35 & 0,33 & 1975,0 & 51,9 & 90,9 & 16,2 \\
\hline $20-40$ & 7,23 & 7,09 & 6,65 & 4,43 & 0,47 & 1937,9 & 56,6 & 91,8 & 16,5 \\
\hline
\end{tabular}

During trial period in years 2003 and 2004 values of mean annual air temperatures were $12,7{ }^{\circ} \mathrm{C}$ and $12,4^{\circ} \mathrm{C}$, which is higher by 0,6 and $0,3^{\circ} \mathrm{C}$ than average determined usually for several years of $12,1^{\circ} \mathrm{C}$. In regard to total precipitation, the two years were significantly different. First year was extremely dry with annual amount of precipitation of $551,9 \mathrm{~mm}$, and the second without dry periods with $831,6 \mathrm{~mm}$.

\section{Results and Discussion}

Because of differences in morphological-physiological traits of plant species, their percentual presence in mixture is of great importance to the yield and quality of forage. Therefore it is important to know stated traits in order to be able to combine them adequately in mixture.

Analysis of floristic composition of samples of green mass (tab.2) showed that in investigated variants the share of leguminous plants, grasses and weeds varied considerably per cuts and years. Mixture as investigated factor showed no statistically significant effect on floristic composition in 2003.

Fertilization had very significant effect on presence of certain plant species in total yield. Differences in share of legumes and grasses were expressed only between treatments without $\mathrm{N}$ and other treatments which was statistically confirmed with probability of $99 \%$. Gradual addition of $\mathrm{N}$ caused decrease of share of legumes, and increase of share of grasses. Percentual presence of legumes depending on fertilization varied from $71,5 \%$ in treatments without fertilization to $60,7 \%$ with $210 \mathrm{~kg} \mathrm{~N} \mathrm{ha}{ }^{-1}$ which in comparison to control was less by $10,8 \%$. Share of grasses, 
contrary to legumes, was the lowest in variant without $\mathrm{N}-29,9 \%$, and the highest in treatment with $210 \mathrm{kgN} \mathrm{ha}^{-1}$ of $38,8 \%$ (more compared to control by $8,9 \%$ ). Interaction of two investigated factors had also very significant

Table 2. Share of groups of plants (\%) in total yield of alfalfa and grass-legume mixtures depending on $\mathbf{N}$ fertilization in years 2003 and 2004

\begin{tabular}{|c|c|c|c|c|c|c|c|}
\hline \multirow{2}{*}{$\begin{array}{l}\text { Mixture } \\
\text { (A) }\end{array}$} & \multirow{2}{*}{$\begin{array}{c}\mathrm{N} \\
\left(\mathbf{B}_{\mathrm{n}}\right)\end{array}$} & \multicolumn{3}{|c|}{2003} & \multicolumn{2}{|c|}{2004} & \multirow[b]{2}{*}{$\mathbf{K}$} \\
\hline & & $\mathbf{L}$ & $T$ & $\mathbf{K}$ & $\mathbf{L}$ & $T$ & \\
\hline \multirow{4}{*}{ Alf. } & 0 & 94,8 & - & 5,1 & 97,5 & - & 2,5 \\
\hline & 70 & 94,2 & - & 5,8 & 96,6 & - & 3,4 \\
\hline & 140 & 90,8 & - & 9,2 & & - & 4,2 \\
\hline & 210 & 90,6 & - & 9,4 & 94,6 & - & 5,4 \\
\hline \multicolumn{2}{|c|}{ Average A } & 92,6 & - & 7,4 & 96,1 & - & 3,9 \\
\hline \multirow{4}{*}{$\begin{array}{c}\text { Mixture } \\
\text { I }\end{array}$} & 0 & 58,9 & 34,2 & 6,9 & 56,8 & 42,4 & 0,8 \\
\hline & 70 & 53,7 & 38,5 & 7,8 & 50,9 & 47,9 & 1,2 \\
\hline & 140 & 47,1 & 41,4 & 11,5 & 39,8 & 58,8 & 1,4 \\
\hline & 210 & 43,5 & 46,3 & 10,4 & 45,2 & 52,9 & 1,9 \\
\hline \multicolumn{2}{|c|}{ Average A } & 50,8 & 40,1 & 9,1 & 48,2 & 50,5 & 1,3 \\
\hline \multirow{4}{*}{$\begin{array}{c}\text { Mixture } \\
\text { II }\end{array}$} & 0 & 61,1 & 32,0 & 6,9 & 63,0 & 36,0 & 1,0 \\
\hline & 70 & 57,2 & 34,9 & 7,8 & 47,2 & 51,5 & 1,3 \\
\hline & 140 & 54,2 & 32,8 & 13,0 & 53,0 & 45,0 & 2,0 \\
\hline & 210 & 51,6 & 36,3 & 12,1 & 45,6 & 50,9 & 3,5 \\
\hline \multicolumn{2}{|c|}{ Average A } & 56,0 & 34,0 & 10,0 & 52,2 & 45,9 & 1,9 \\
\hline \multirow{4}{*}{$\begin{array}{l}\text { Mixture } \\
\text { III }\end{array}$} & 0 & 71,2 & 23,6 & 5,2 & 53,9 & 44,5 & 1,6 \\
\hline & 70 & 52,5 & 40,6 & 6,9 & 50,0 & 48,0 & 2,0 \\
\hline & 140 & 53,8 & 39,4 & 6,8 & 48,6 & 49,4 & 2,0 \\
\hline & 210 & 57,3 & 33,7 & 9,0 & 44,8 & 52,2 & 3,0 \\
\hline \multicolumn{2}{|c|}{ Average A } & 59,0 & 34,0 & 7,0 & 49,3 & 48,5 & 2,2 \\
\hline \multirow{4}{*}{$\begin{array}{c}\text { Average } \\
\text { B }\end{array}$} & 0 & 71,5 & 29,9 & 6,0 & 67,8 & 40,9 & 1,5 \\
\hline & 70 & 64,4 & 38,0 & 7,1 & 61,2 & 49,1 & 2,0 \\
\hline & 140 & 61,5 & 37,9 & 10,1 & 59,3 & 51,1 & 2,4 \\
\hline & 210 & 60,7 & 38,8 & 10,2 & 57,5 & 52,0 & 3,4 \\
\hline \multirow{2}{*}{ Group } & \multirow{2}{*}{ LSD } & & 2003 & & & 2004 & \\
\hline & & $\mathbf{A}$ & B & $\mathbf{A B}$ & A & B & $\mathbf{A B}$ \\
\hline \multirow{2}{*}{$\mathbf{L}$} & 0,01 & $18,4648 * *$ & $4,9184 * *$ & $20,5830 * *$ & 12,0024 & $3,0390 * *$ & $13,2343 * *$ \\
\hline & 0,05 & 12,1886 & 3,6295 & 13,8405 & $8,3537 *$ & 2,3087 & 9,3283 \\
\hline \multirow{2}{*}{$\mathbf{T}$} & 0,01 & 21,2872 & $6,6656^{* *}$ & 23,8970 & 8,0069 & $4,3400 * *$ & $10,5132 * *$ \\
\hline & 0,05 & 12,8352 & 4,8660 & $14,9871 *$ & $5,2854 *$ & 3,2139 & 7,2534 \\
\hline \multirow{2}{*}{$\mathbf{K}$} & 0,01 & 3,2674 & $2,0610 * *$ & $4,9269 * *$ & $0,8397 * *$ & $0,4721 * *$ & $1,1918 * *$ \\
\hline & 0,05 & $2,1568 *$ & 1,5209 & 3,4491 & 0,5844 & 0,3587 & 0,8631 \\
\hline
\end{tabular}

$\mathrm{L}=$ legumes; $\mathrm{T}=$ grasses; $\mathrm{K}=$ weed plants 
influence on presence of legumes, which varied from $71,2 \%$ in mixture III without $\mathrm{N}$, to $43,5 \%$ in mixture I with $210 \mathrm{~kg} \mathrm{~N} \mathrm{ha}^{-1}$, which is difference of $27,7 \%$. Mixture and fertilization had considerable effect on share of grasses in forage yield. The highest share was realized in mixture I with $210 \mathrm{~kg} \mathrm{~N}$ $\mathrm{ha}^{-1}$ of $46,3 \%$, and the lowest in mixture III with $\mathrm{N} 23,6 \%$ or 2,05 times less.

Presence of weed species in mixtures was very dependent on fertilization and mutual effect between investigated factors. Share of weeds varied from $7,0 \%$ in mixture III, which in relation to pure alfalfa was less by $0,4 \%$, to $10,0 \%$ in mixture II i.e. higher by $2,6 \%$. Fertilization increased the share of weeds of $6,0 \%$ in variants without fertilization to $10,2 \%$ in variants with the highest amount of nitrogen.

Analysis of floristic composition in the second investigation year determined that share of legumes decreased, and share of grasses increased in relation to the first investigation year. Mixture had very significant effect on share of legumes and significant on share of grasses in yield of forage. The highest percentual presence of legumes was realized in mixture II 52,2, and the lowest in mixture I 48,2\%. Grasses had the highest presence in the first mixture 50,5, and the lowest in mixture II 45,9\%.

Fertilization had statistically highly significant effect on share of legumes and grasses in mixtures. Differences at the level of significance of $\mathrm{p}<0,01$ occurred only between treatments without $\mathrm{N}$ and other treatments. In variants without fertilization legumes realized the highest presence of $67,8 \%$, and grasses the lowest $40,9 \%$, whereas the variants with $210 \mathrm{~kg} \mathrm{~N}^{-1}$ had the least legumes $57,5 \%$ (less by $10,3 \%$ than control treatment) and the most grasses $52,0 \%$ (more by $11,1 \%$ ). Interaction mixture-fertilization also had statistically very significant effect on floristic composition. The most favourable ratio of legumes and grasses in favour of legumes was in mixture II N0 63,0\%: 36,0\%, and the most favourable ratio to the benefit of grasses in mixture I $140 \mathrm{~N} 39,8 \%: 58,8 \%$.

Weed plants, compared to previous year, had slight effect on structure of yield of mixtures since their presence was reduced to expected level. Their share was highly dependent on both investigated factors. Differences with degree of probability of $99 \%$ were expressed only between alfalfa in pure sowing which had the highest percentual share of weeds 3,9\% and other mixtures, as well as between mixtures III and II. Fertilization leads to increase of share of weeds in mixtures. Most of weeds was determined in treatments with $210 \mathrm{~kg} \mathrm{~N} \mathrm{ha}^{-1}$ of 3,4\%, and the least in treatments without $\mathrm{N}$ of $1,5 \%$. Depending on the year and cut, following weed species had higher frequency: Stellaria media, Chenopodium album, Ambrosia artemisifolia, 
Panicum crus-galli, Setaria viridis, and Sorghum halepense.

By analysis of floristic composition of alfalfa and grass-legume mixtures, and depending on fertilization with $\mathrm{N}$, we concluded that alfalfa was dominant in all mixtures, which is in accordance with research of Heichel and Henjum (1991); Adamovich and Adamovich (2003). In mixture of alfalfa and cock's foot (mixture I) percentual share of both species remained on the level like at sowing with slight variations $\pm 1 \%-10 \%$ depending on the year, which according to Mišković et al. (1983) and Ocokoljić et al. (1984) is a sign of good competitive abilities of cock's foot in growing with alfalfa. In mixture where beside cock's foot also tall fescue is present, considerable decrease of percentual share of grasses in the yield is noticed compared to initial ratio at sowing, regardless of the time of utilization. Although Casler and Walgenbach (1990) stated that cock's foot and tall fescue survive in mixture with alfalfa it is considered that this is consequence of poor competitive ability of tall fescue to be grown in mixture (Vassilev, 2004) compared to cock's foot (Undersander et. al., 2001) and alfalfa (Novy et. al., 1995) which are very aggressive and competitive species. Similar results were obtained by Zoghlami (2000) who investigated the mixture of alfalfa and tall fescue and concluded that in the second year the tall fescue was suppressed from the mixture, causing the increase of share of alfalfa from $46 \%$ to $84,0 \%$. Similar to our results, many authors in their researches concluded that fertilization with $\mathrm{N}$ had great influence on botanical composition of mixture, by leading to decrease of share of legumes and increase of share of grasses (Laidlaw and Withers, 1998 and Berdahl et. al., 2001). Mijatović, (1975) pointed out that fertilization regulated the ratio of mixture components, stressing the share of better grasses, increasing the density of crops and preventing the infiltration by weeds. This can also explain the decrease of share of weeds in mixtures, and their increase in pure alfalfa crop.

On graphs 1 and 2 the shares of certain plant species in forage mixtures per cuts in years 2003 and 2004 are presented. On both graphs it is obvious that grasses decrease their share in the middle of vegetation, during hot summer months, leaving the room for greater presence of legumes which bear dry conditions much better due to deep root system. Share of weed plants during exploitation season, in forage mixture, shows the same tendency as grasses. Our research can be confirmed by researches of other authors (Dubljević, 1991; Vassilev, 2004) who came to similar conclusions. 


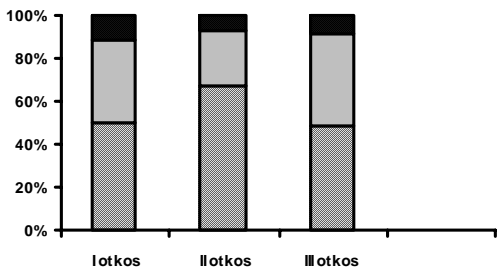

Graph 1. Share of plant species in mixtures per cuts in 2003

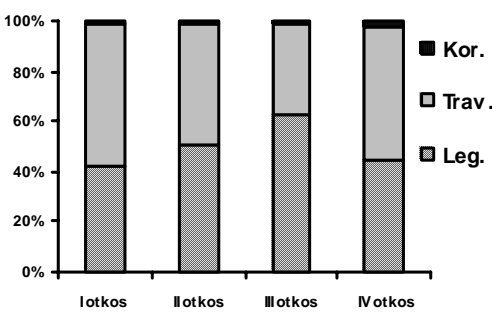

Graph 2. Share of plant species in mixtures per cuts in 2003

\section{Conclusion}

Mixture is very significant for share of legumes and weeds, and significant for share of grasses in total yield of forage, whereas with fertilization very significant effect on all investigated groups was achieved. In both years, and based on realized share/presence in yield, we can conclude that cock's foot is more competitive for growing in mixture with alfalfa than tall fescue and sain foin. Weed species, due to the increase of density of crops had lower share in mixtures than in monoculture. Fertilization increased the share of grasses and weeds, and decreased the share of legumes in both investigation years. Variants without fertilization had the highest share of legumes, and the lowest of grasses and weeds and opposite situation occurred in variants with the highest applied amount of nitrogen.

Based on previous experiences, for intensive livestock production and production of high quality livestock feed, mixtures of alfalfa with one or two 
competitive grass species can be recommended, in our case cock's foot which should be fertilized with medium amounts of $\mathrm{N}$ of 70-140 $\mathrm{kg} \mathrm{ha}^{-1}$.

\title{
PROMENE BOTANIČKOG SASTAVA LUCERKINIH SMEŠA U ZAVISNOSTI OD VRSTA U SMEŠI I DJUBRENJA N
}

\author{
Z. Nešić, Z. Tomić, S. Vučković, V. Krnjaja, S. Josipović, \\ D. Ružić-Muslić
}

\section{Rezime}

Lucerka je najvažnija krmna biljka kod nas. Uglavnom se gaji kao čist usev za ishranu stoke, mada veoma dobre rezultate daje gajenjem u smeši sa drugim biljnim vrstama. Gajenjem u smešama ostvaruje se čitav niz prednosti od kojih su najvažnije: mogućnost korišćenja lucerke $u$ ispaši i smanjenje potrebe đubrenja travnjaka. U dvogodišnjem ogledu (2003-2004) praćene su promene $\mathrm{u}$ botaničkom sastavu lucerkinih smeša u zavisnosti od prisutnih vrsta $u$ smeši odnosno njihovih kompeticionih sposobnosti i djubrenja $\mathrm{N}$. Ispitivanja su pokazala da sa starenjem useva dolazi do povećanja udela trava, a smanjenja udela leguminoza i korova. Djubrenje je pokazalo pozitivan efekat na jačanje kompeticionih sposobnosti travnih $\mathrm{u}$ odnosu na leguminozne vrste i povećan udeo korova u krmi smeša.

\section{References}

ADAMOVICH A. and ADAMOVICHA O. (2003): Productivity and forage quality of Festulolium/legume mixed swards in response to cutting frequency. Grassland Science in Europe, Vol. 8, 453-456.

BERDAHL, J. D., KARU, J. F., HENDRICKSON, J. R. (2001): Dry matter yield of cool-seson Grass Monocultures and grass-alfalfa binary mixtures. Agronomy Journal, Vol. 93, 463-467.

CASLER, D. M. and WALGENBACH, R. P. (1990): Ground cover potential of forage grass cultivars mixed with alfalfa at divergent locations. Crop Science. Vol. 30, No. 4, 825-831.

DUBLJEVIĆ, G. R. (1991): Proizvodna vrednost travno-leguminoznih smeša u zavisnosti od njihovog sastava. Magistarski rad, Poljoprivredni 
fakultet Zemun.

ĐORĐEVIĆ, N. i DINIĆ, B. (2003): Siliranje leguminoza. Institut za istraživanja u poljoprivredi SRBIJA, Beograd, 226.

FRAME, J. and LAIDLAW S.A. (1998): Managing white clover in mixed swards principles and practice. Pastos, Vol. XXVIII (1), 5-33.

HEICHEL, G.H., HENJUM, K.I. (1991): Dinitrogen fixaion, nitrogen transfer and productivity of forage legume- grass communities. Crop Science, Vol. 31, No. 1, 202-208.

HOVELAND, C.S., DURHAM, R.G., BOUTON, J.H. (1995): Management effects on productivity of alfagraze alfalfa-tall fescue mixtures. Journal of Production Agriculture, Vol. 8, No. 2, 244-248.

LAIDLAW, A.S. and WITHERS, J.A. (1998): Changes in contribution of white clover to conopy structure in perennial ryegrass/white clover swards in response to $\mathrm{N}$ fertilizer. Grass and Forage Science, Vol. 53., 287-291.

MIJATOVIĆ, M. (1975): Veštački travnjaci kao faktor racionalnog iskorišćavanja zemljišta u brdskom i planinskom području.

Agrohemija, Br. 1-2, 41-51.

MIŠKOVIĆ, B., ERIĆ, P., STEFANOVIĆ, LJ. (1983): Zavisnost sadržaja sirovih proteina i sirove celuloze u senu kulturnih travnjaka od odnosa trava i legiminoza u smeši na ridskom i alkalirotskom zemljištu. Zbornik radova, IV jugoslovenski simpozijum o krmnom bilju,. 247-260.

NOVY, M., CASLER, M.D., HILL, R.R. (1995): Selection for persistance of tetraploid ryegrasses and festulolium in mixture with perennial legumes. Crop Science, Vol. 35, 1046-1051.

OCOKOLJIĆ, S., VELIČKOVIĆ, G., PARIS, Z., NINKOVIĆ, S. (1984): Uticaj različitih nivoa đubrenja azotnim i NPK đubrivima na prinos, botanički i hemijski sastav i sadržaj nekih važnijih aminokiselina kod smeše ježevice (Dactylis glomerata) i žutog zvezdana (Lotus corniculatus). Agrohemija, No. 4, 265-274.

UNDERSANDER, J.D., WEST, C.D., CASLER, D.M. (2001): Sward Dynamics and pasture productivity. Agronomy Journal, Vol. 93, 609-619.

VASSILEV, E. (2004): Forage productivity of some Bulgarian lucerne in mixtures with grasses. Proceeding of the $20^{\text {th }}$ European Grassland Federation, Land use systems in Grassland Dominated Regions. Grassland Science in Europe, Vol. 9, 401-403.

ZOGHLAMI, A. (2000): Preliminary results on the effect of seeding methods on production and botanical composition of perennial mixtures of alfalfa-grasses. CIHEAM- Options Mediterraneennes, 203-206.

TEKELI, S.A. and ATES, E. (2005): Yield potential and mineral 
composition of white clover (Trifolium repens L.) and tall fescue ( Festuca arundinaceae Schreb.) mixtures. Journal of Central European Agriculture, Vol. 6, No. 1, 27-34.

WHITE, L. M. and WIGHT, R. J. (1984): Forage yield and quality of dryland grasses and legumes. Journal of Range Management. Vol. 46, 233236. 